\title{
CCR4 wt Allele
}

National Cancer Institute

\section{Source}

National Cancer Institute. CCR4 wt Allele. NCI Thesaurus. Code C129066.

Human CCR4 wild-type allele is located in the vicinity of 3p24 and is approximately $5 \mathrm{~kb}$ in length. This allele, which encodes C-C chemokine receptor type 4 protein, plays a role in leukocyte migration. 